Role of agricultural engineering in environmental and sustainable development for the valley and delta areas. 1651 - 1673

\title{
AIR-ASSISTED SPRAYING AND ITS DRIFT
}

\section{Rasmy, A. S. ; A. A. M. EL-Meseery ${ }^{1}$; A. A. Abd-El Fatah ${ }^{2}$ and A. M. I. Rezk ${ }^{3}$}

\section{$\underline{\text { ABSTRACT }}$}

The main objective of this investigation is to study and evaluate the spraying factors affecting on spray drift and the environment pollution using air-assisted spraying technique (twin spraying technique). The airassisted spraying device was modified and fabricated in some private local workshops at Dmanhour city, EL-Behira Governorate, Egypt. The experiments were divided in two operation conditions, as with and without air-assistance. The variables of study were four levels of spray height 30, 40, 50 and $60 \mathrm{~cm}$, three types of nozzle (flat fan $110^{\circ}$ ) tip sizes 1, 3 and 5mm and four levels of operation pressure 1.5, 2.5, 3.5 and 4.5 bar. The performance indicators of spraying device were coefficient of uniformity (CU\%) of spray patternator distribution. The results were as: The maximum values of (CU\%) due to using air assisted unit were 87.25, 96.06 and 88.24\% at spray height $40 \mathrm{~cm}$ and spray pressure 2.5bar by using nozzle tip size of $1 \mathrm{~mm}, 3 \mathrm{~mm}$ and $5 \mathrm{~mm}$, respectively. Meanwhile, the lowest values were 77.54, 86.23 and $80.81 \%$ at spray height $60 \mathrm{~cm}$ by using nozzle tip size of $1 \mathrm{~mm}, 3 \mathrm{~mm}$ and $5 \mathrm{~mm}$, respectively without air. The off-target distance decreased from 7 to $4 \mathrm{~m}$ at spray height $40 \mathrm{~cm}$ by using nozzle tip size of $3 \mathrm{~mm}$, average wind speed $1.26 \mathrm{~m} / \mathrm{s}$ using air assistance technique. The obtained values of (VMD) increased by using the same nozzle tip size $3 \mathrm{~mm}$ and spray height $40 \mathrm{~cm}$ from $209.98 \mu \mathrm{m}$ without air assistance to $235.18 \mu \mathrm{m}$ with air assisted unit. The values of deposition rate increased to $0.472,0.468,0.446$ and $0.462 \mathrm{~mm}^{3} / \mathrm{cm}^{2}$ at the top plant level and increased to $0.389,0.384,0.360$ and $0.360 \mathrm{~mm}^{3} / \mathrm{cm}^{2}$ at the bottom plant level when using nozzle tip size of $1 \mathrm{~mm}$ and with air assisted unit at spray height of $40 \mathrm{~cm}$ and spray pressure levels of 1.5, 2.5, 3.5 and 4.5 bar respectively.

\footnotetext{
${ }^{1}$ Ass. Prof. of Agric. Eng., Agric. Eng. Dept., Fac. of Agric., Al-Azhar U.

${ }^{2}$ Senior Res., Plant Prot. Ins., Agri. Res.

${ }^{3}$ Master Stud. ., Agric. Eng. Dept., Fac. of Agric., Al-Azhar U.
} 
Recommendation: using air assisting technique for increased of uniformity and decreased the drift.

\section{INTRODUCTION}

$\mathrm{P}$ rimary task of sprayers is to deliver the working fluid to the target surface in a finely divided form. The operating process of any sprayer consists of delivering the working fluid either by a pump or by air pressure for the reservoir to the spraying device nozzle that atomizes it into fine droplets and the desired spray forms. The spray drift is defined as the movement of a pesticide through the air, during or after application, to a site other than the intended target. The drift may be influenced by various factors: (1)Meteorological factors: wind speed, atmospheric stability, turbulence, temperature and humidity; (2) Application factors: sprayer type, nozzle type, nozzle size, nozzle pressure, release height, angle at which the pesticides are spread and driving speed; (3) Formulation: additives, density and viscosity (Combellack, 1982). The air-assisted spraying is an effective method of improving spray penetration and reducing spray drift (Hadar, 1991). Airassisted sprayers use air jets to carry pesticide droplets to the target position, to displace the air inside the crop canopy and to assist a uniform deposition of the pesticide droplets on the targeted surface ( Da Silva et al., 2006; Delele et al., 2005). Kappel and Stentrop (2003) classified the types of air assisted spraying systems according to the function of air and the operation principles as follows:-

1- Air assisted nozzle. (pneumatic)

2- Sleeve boom. (perforated air bag along the boom distribute)

3- Vacuum system. (indirect use of air assistance, sleeve boom type air bag )

4- Twin system. The twin system is defined as the only air assisted sprayer with the patented possibility to angle air and liquid together in such a way that it is possible to counteract wind direction and forward speed. Hardi International Technical Report (1988-1993) showed that twin air assisted sprayer makes it possible to angle the "aircurtain" together with the spray swath of drops, thereby making it possible to compensate for the direction of the wind. 
The main objectives of this investigation are:-

1. Construct the prototype air assisted spray device.

2. Study some engineering factors which affect drift when using air assisted spray device.

3. Increase the spray distribution efficiency and spray control efficiency.

\section{MATERIALS AND METHODS}

The laboratory device of air-assisted spraying was fabricated in private local workshops at Dmanhour city, EL-Behira Governorate (دمنهور-بحيرة). The main specifications of the laboratory spray device of air-assisted unit are summarized in Table (1). Fig. (1): Schematic drawing of air nozzle and Liquid nozzle and its directions. The main components of the spray device are illustrated in Fig. (2)

To estimate and evaluate the effect of factors on the spray drift and spray efficiency, some factors were taken under consideration as: spray height, 30, 40, 50 and $60 \mathrm{~cm}$, spray pressures, 1.5, 2.5, 3.5 and 4.5 bar and nozzle tip size, 01 orange, 03-blue and 05-brown $\mathrm{mm}$. the number before the color means diameter of nozzle and the color shows the categories of nozzle (ASAE S-572 spray tip classification by droplet size).

Classification categories, symbols and corresponding color codes are as follows:

\begin{tabular}{|c|c|c|}
\hline $\begin{array}{l}\text { Classification } \\
\text { Category }\end{array}$ & Color Code & Approximate VMD \\
\hline Very Fine $\ldots \ldots \ldots \ldots$ VF & Red & $<100$ \\
\hline Fine $\ldots \ldots \ldots$ & Orange & $100-175$ \\
\hline Medium $\ldots \ldots \ldots \ldots \ldots$ M & Yellow & $175-250$ \\
\hline Coarse $\ldots \ldots \ldots \ldots \ldots$ C & Blue & $250-375$ \\
\hline Very Coarse .......... VC & Green & $375-450$ \\
\hline Extremely Coarse $\ldots \ldots \ldots$ XC & White & $>450$ \\
\hline
\end{tabular}




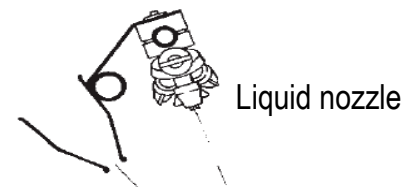

air nozzle

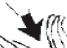

Fig. (1): Schematic drawing of air nozzle and Liquid nozzle and its directions.
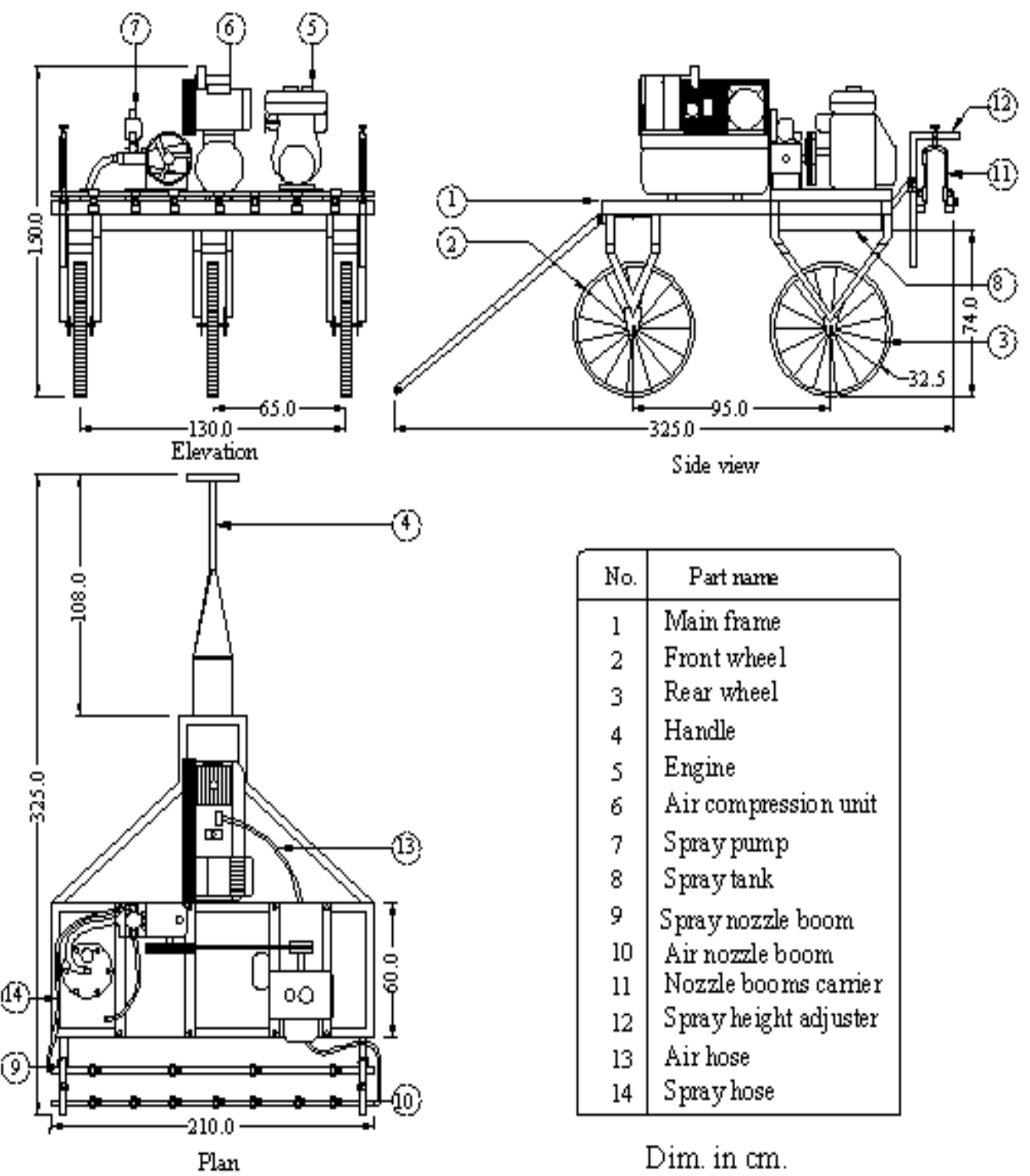

(4)

\begin{tabular}{|c|l|}
\hline No. & Part name \\
\hline 1 & Main frame \\
2 & Front wheel \\
3 & Rear wheel \\
4 & Handle \\
5 & Engine \\
6 & Air compression unit \\
7 & Spray pump \\
8 & Spray tark \\
9 & Spray nozzle boom \\
10 & Air nozzle boom \\
11 & Nozzle booms camier \\
12 & Spray height adjuster \\
13 & Air hose \\
14 & Spray hose \\
\hline
\end{tabular}

Dim. in cm.

Fig. (2): Schematic drawing of laboratory air assisted spray device. 
Table (1): The main specifications of the laboratory spraying device of air-assisted unit.

\begin{tabular}{|c|c|c|}
\hline \multicolumn{3}{|c|}{ specifications } \\
\hline Overall length & $(\mathrm{cm})$ & 325 \\
\hline Overall width & $(\mathrm{cm})$ & 210 \\
\hline Overall height & $(\mathrm{cm})$ & 150 \\
\hline Ground clearan & $(\mathrm{cm})$ & 65 \\
\hline \multirow{7}{*}{ Engine } & Engine type & Yanmar \\
\hline & Cooling system & Air cooled \\
\hline & Max. output & $5 \mathrm{HP}$ \\
\hline & Fuel type & Gasoline \\
\hline & Capacity of fuel tank (1) & 5 \\
\hline & Starting method & By robe \\
\hline & Number of cylinders & 1 \\
\hline \multirow{5}{*}{ Spray pump } & Type and model & WULE, WL-45 B \\
\hline & Dimensions ( L $x \mathrm{H} \times \mathrm{W}$ ) & $397 \times 308 \times 370$ \\
\hline & Mass & $15.5 \mathrm{~kg}$ \\
\hline & Max. pressure & 35 bar \\
\hline & Discharge & $40 \mathrm{l} / \mathrm{min}$ \\
\hline \multirow{8}{*}{$\begin{array}{l}\text { Air } \\
\text { compression } \\
\text { unit }\end{array}$} & Type and model & Royal -3.00 \\
\hline & Power source & $3 \mathrm{HP}(2.2 \mathrm{~kW})$ \\
\hline & Output capacity & $170 \mathrm{l} / \mathrm{min}$ \\
\hline & pressure & $80 \mathrm{~N} / \mathrm{cm}^{2}$ \\
\hline & Tank capacity & 501 \\
\hline & Mass & $50 \mathrm{~kg}$ \\
\hline & Tank diameter & $50 \mathrm{~cm}$ \\
\hline & \begin{tabular}{|l|} 
Tank length \\
\end{tabular} & $115.9 \mathrm{~cm}$ \\
\hline \multirow{6}{*}{$\begin{array}{l}\text { Air and spray } \\
\text { booms holder } \\
\text { unit }\end{array}$} & length & $200 \mathrm{~cm}$ \\
\hline & Max. height & $140 \mathrm{~cm}$ \\
\hline & \begin{tabular}{|l} 
Min. height \\
\end{tabular} & $30 \mathrm{~cm}$ \\
\hline & Nozzle spacing & $50 \mathrm{~cm}$ \\
\hline & \begin{tabular}{|l|} 
Nozzle type \\
\end{tabular} & Hardi ISO $110^{\circ}$ flat fan \\
\hline & Number of nozzle & 4 \\
\hline \multirow{4}{*}{$\begin{array}{l}\text { Spray solution } \\
\text { tank }\end{array}$} & Length & $150 \mathrm{~cm}$ \\
\hline & Width & $50 \mathrm{~cm}$ \\
\hline & Height & $14 \mathrm{~cm}$ \\
\hline & Capacity & 100 liters \\
\hline
\end{tabular}




\section{1- Spray pattern distribution characteristics}

\section{1-1Spray volume}

A patternator table was used to determine discharge spray volume in collected pockets during operating the laboratory spraying device with and without using air assisted technique. The laboratory device was operated and adjusted under the study parameters as spray pressure, spray height and nozzle size without and with air assisting unit using tap water at $25^{\circ} \mathrm{c}$ as the spray liquid. After each experiment, the spray in the collectors under patternerator grooves was taken and weighed to estimate the spray volume.

\section{1-2 Coefficients of variance (CV\%.) and uniformity (CU\%)}

The measurements of distribution patterns were carried out using the data collected from patternator table under the study parameters. The coefficient of variation $(\mathrm{CV} \%)$ and spray uniformity $(\mathrm{CU} \%)$ in the distribution pattern were calculated between the centers of nozzles across the boom using the standard deviation $(\delta)$ and coefficient of variation $(C V \%)$ equations according to Ozkan et al., (1992)

$$
\begin{aligned}
& \bar{x}=\frac{\sum x_{i}}{n} \text {-------------------------------- (1) } \\
& \delta=\sqrt{\frac{\sum\left(x_{i}-\bar{x}\right)^{2}}{n-1}} \\
& C . V=\frac{\delta}{x} \times 100
\end{aligned}
$$

Where:

$$
\begin{gathered}
x_{i}=\text { the individual collection point from the swath width (Amount } \\
\text { of spray deposited in a cylinder in the spray swath). } \\
\bar{x}=\text { the arithmetic mean of collection points across the spray } \\
\text { swath. (Mean of spray distribution across the spray swath.) } \\
n=\text { number of collection points (Number of measurements) } \\
\delta=\text { standard deviation; and } C V \%=\text { coefficient of variation. }
\end{gathered}
$$


The spray uniformity $(S U \%)$ in the distribution pattern, for each experimental treatment could be estimated using the following formula according to ASAE Standard (1992):-

$$
C U \%=100-C V \text { - }
$$

\section{$\underline{\text { 2-Spray deposition characteristics }}$}

\section{2-1 flow rate}

Awady (2000) showed that the droplet size varies with the nozzle area (with $\mathrm{d}^{2}$ ) and with the inverse of the pressure square root.

$$
q=d^{\pi} / \sqrt{p},
$$

Where: $d=$ Diameter of nozzle "mm"

$$
\mathrm{P}=\text { Operation pressure "bar" }
$$

\section{2-1 number of droplets $/ \mathrm{cm}^{2}$}

A yellow water sensitive paper was used as an artificial surface to receive spray droplets that deposit on upper and lower surfaces of cotton plant leaves. The depositing spray droplets number on upper and lower plant leaf surfaces were counted in one square centimeter for each spray treatments by scanning the water sensitive paper on the computer and magnifying it to about $60 x$.

\section{2-2 Volume mean diameter (VMD)}

Volume median diameter was estimated in this study by measuring the droplet sizes for laboratory air assisted spraying device using water sensitive paper magnified to about $60 \mathrm{x}$, then the horizontal and vertical diameters were measured and converted to original size in $\mu \mathrm{m}$. The results were recorded, classified in successive classes (with a range of 50 microns) and the spray droplet size was calculated expressed in volume median diameter $(V M D)$ according to the following equation:-

$$
\text { VMD }=\left[\sum_{\mathrm{i}=1}^{\mathrm{i}=\mathrm{n}} \mathbf{n}_{\mathrm{i}} \mathbf{x}_{\mathrm{i}}^{3} / \sum_{\mathrm{i}=1}^{\mathrm{i}=\mathrm{n}_{1}} \mathbf{n}_{\mathrm{i}}\right]^{\frac{1}{3}}---(7)
$$

Where : 
$n_{i}=$ Number of droplets at each classification droplet size

$x_{i}=$ Mean droplet diameter for a given class.

\section{2-3-Spray deposition rate}

For calculating deposition rate, the following equation was used:

$$
D_{r}=n\left(4 / 3 \pi r^{3}\right)-----(8)
$$

Where:

$$
\begin{aligned}
& \boldsymbol{D}_{\boldsymbol{r}}=\text { deposition rate }\left(\mathrm{mm}^{3} / \mathrm{cm}^{2}\right) . \\
& \boldsymbol{n}=\text { No. of droplets } / \mathrm{cm}^{2} . \\
& \boldsymbol{r}=\frac{\text { VM.D }}{\pi} \ln (\mathrm{mm})
\end{aligned}
$$

\section{2-4- Spray deposition ratio}

The spray deposit ratio $(\lambda)$ between the upper and lower surfaces of plant leaves was determined for laboratory spraying device as follows :

$$
\lambda=\frac{S D_{\text {lower }}}{S D_{\text {upper }}}
$$

Where :

$$
\begin{aligned}
& S D_{\text {lower }}=\text { Spray deposit on the lower leaf surface, No. } / \mathrm{cm}^{2} \text {, } \\
& S D_{\text {upper }}=\text { Spray deposit on the upper leaf surface, } \\
& \text { No. } / \mathrm{cm}^{2}
\end{aligned}
$$

\section{2-5-Spray drift deposition}

The spray drift deposition measurement was conducted by using the water sensitive paper as following:-

1- The drift deposition was evaluated at 1,2,3,4,7 and $12 \mathrm{~m}$ from last nozzle under the experiment conditions of $40 \mathrm{~cm}$ nozzle spacing boom height above crop $50 \mathrm{~cm}$. The wind direction was perpendicular to driving direction, average wind speed was $1.26 \mathrm{~m} / \mathrm{s}$, average RH 53.78 $\%$, and average air temperature $31.1^{\circ} \mathrm{c}$.

2- Spray drift measurements were carried out by passing the air assisted spraying device on the cotton plants swath and operating the spray 
device to apply spray on the cotton plants with and without using the air assisted technique.

3- The water sensitive paper placed inside the cotton plants rows and outside the plants swath were collected and the droplets number and diameters were determined to estimate the air borne spray drift occurred on the different distances from the last downwind nozzle by using the number of droplets $/ \mathrm{cm}^{2}$ and volume median diameter .

\section{RESULTS AND DISCUSSION}

The spray flow rate, total spray volume, average nozzle spray volume, coefficient of variance, uniformity coefficient, symmetry, deposition rate droplets diameters, numbers of droplets and droplets drift were measured as indicators to spray quality and spray efficiency.

\section{Effect of operation pressure and nozzle size on flow rate}

Fig. (1) illustrates the relation between average flow rate (q) $1 / \mathrm{min}$ and operating pressure $(\mathrm{P})$ "bar" at different diameters of nozzle.

The relation was power equation as :

$$
\mathbf{q}=\mathbf{a} \mathbf{P}^{\mathrm{B}}
$$

The parameter "a" depends on area of nozzle. The parameter "B" depends on type of flow, the mean of parameter "B" was 0.536, compared with Awady (2000) who showed that "q" varies with the square root of pressure. .

Figs. (2) illustrates the relation between parameter " a " and area of nozzle. The relation is linear as:

$$
\mathrm{a}=0.046 \mathrm{Dn}^{2} \ldots . .(\mathrm{R} 2=0.909) \text {. }
$$

From equation s (1) and (2). The equations (1) became as:

$$
q=0.046 \mathrm{Dn}^{2} \mathrm{P}^{0.536}
$$

Where:

$\mathbf{q}=$ Flow rate of nozzle $" 1 / \mathrm{min} "$

Dn = Diameter of nozzle "mm"

$\mathbf{P}=$ Operation pressure "bar" 


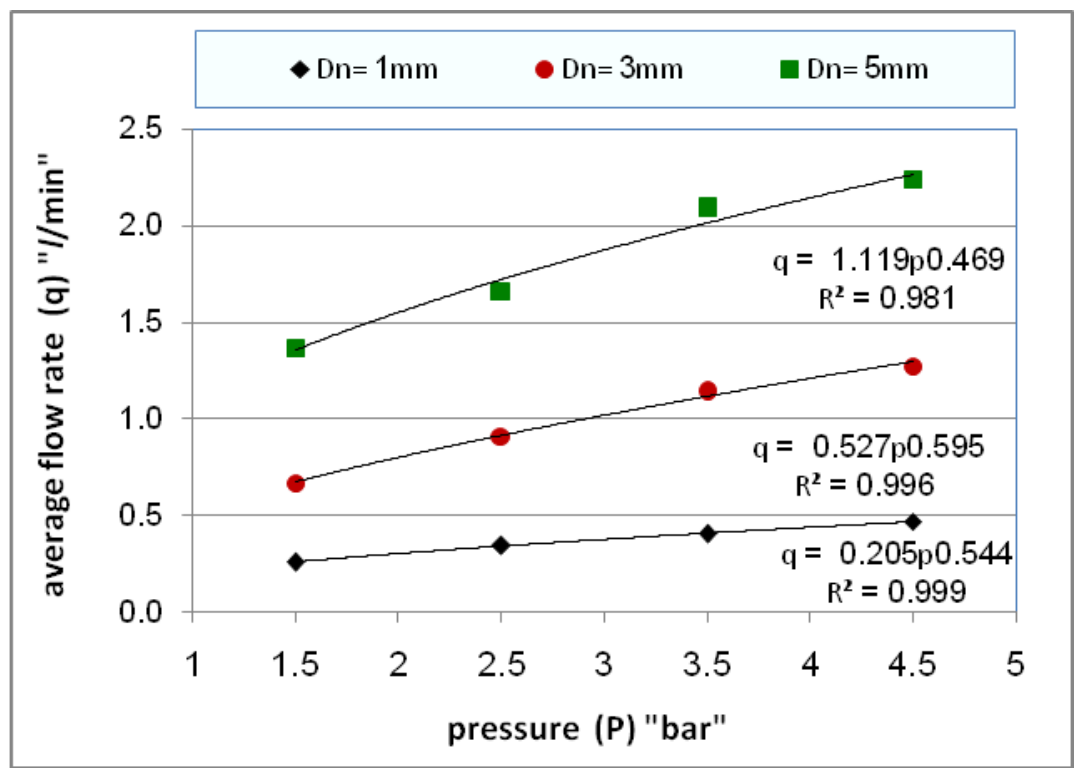

Fig.(1): Relation between average nozzle flow rate and pressure at different diameter.

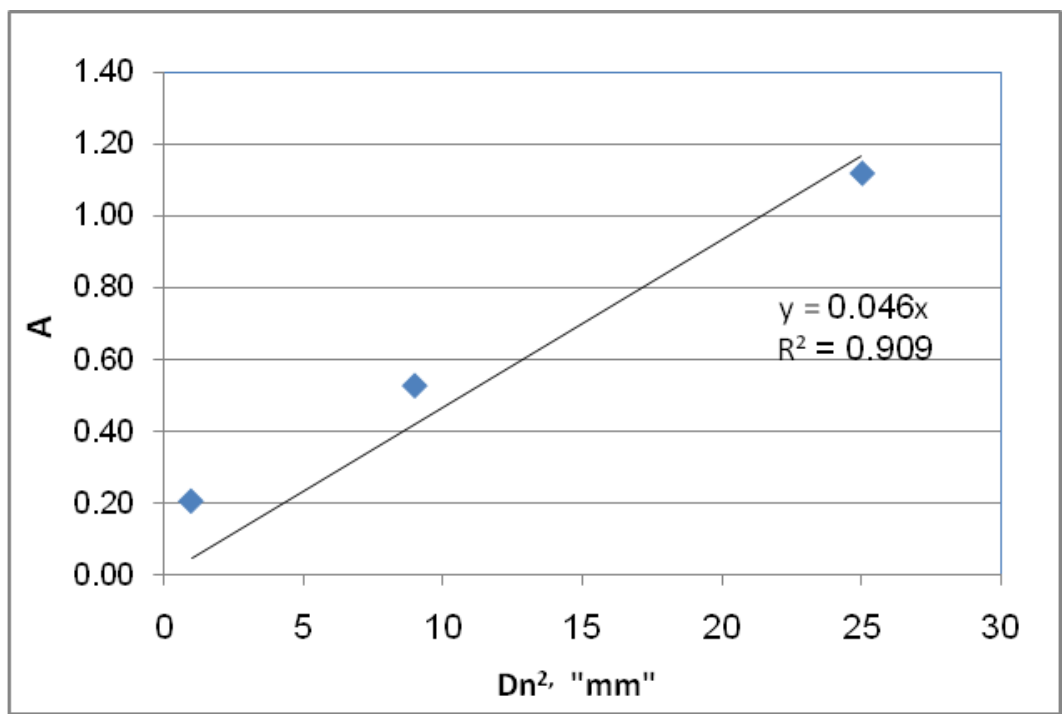

Fig.(2): Relation between parameter "a" at different nozzle diameters. 


\section{Effect of air assisting on spray quality and spray efficiency}

\section{Effect of pressure, spray height and nozzle tip size on spray uniformity with and without air assisting}

Fig.(3) shows the effect of spray height and spray nozzle size on the coefficient of uniformity (CU\%) using laboratory spraying device with and without air assisted unit. The effect of using the air assisted unit was highly improved with using air assisted unit than that without. The maximum values of (CU\%) due to using air assisted unit were 87.25, 96.06 and $88.24 \%$ at spray height $40 \mathrm{~cm}$ and spray pressure 2.5 bar by using nozzle tip size of $1 \mathrm{~mm}, 3 \mathrm{~mm}$ and $5 \mathrm{~mm}$, respectively. Meanwhile, the lowest values were $77.54,86.95$ and $80.81 \%$ at spray height $60 \mathrm{~cm}$ and spray pressure 2.5 bar by using nozzle tip size of $1 \mathrm{~mm}, 3 \mathrm{~mm}$ and $5 \mathrm{~mm}$, respectively, without air assisted.

\section{Effect of air assisting on spray drift \\ Off- target spray distance}

Fig.(4) shows the number of droplets $/ \mathrm{cm}^{2}$ drifting outside of the target area at 1, 2, 4, 7, and $12 \mathrm{~m}$ from the last nozzle on the sprayer, which collected by water sensitive paper under different study parameters. These results conclude that the number of droplets drifted outside target area were highly affected by using the air assisted unit compared without using it, as with spray pressure and height. The number of droplets $/ \mathrm{cm}^{2}$ drift off-target area was found to be 9.73, 4.76, 2.66, 1.24 and 0.00 droplets $/ \mathrm{cm}^{2}$ at distances of $1,2,4,7$, and $12 \mathrm{~m}$ respectively, without using air assisted units compared with 5.88, 3.12, 1.56, 0.00 and 0.00 droplets $/ \mathrm{cm}^{2}$ by using air assisted unit under $40 \mathrm{~cm}$ spray height, $3 \mathrm{~mm}$ nozzle tip size and 4.5 bar spray pressure.

The highest value of droplets number $/ \mathrm{cm}^{2}$ was obtained at distance of $1 \mathrm{~m}$ from last nozzle at spray pressure of 4.5 bar and spray height of $60 \mathrm{~cm}$ at any given nozzle tip size under study by using laboratory spraying device with and without air assisted unit. 


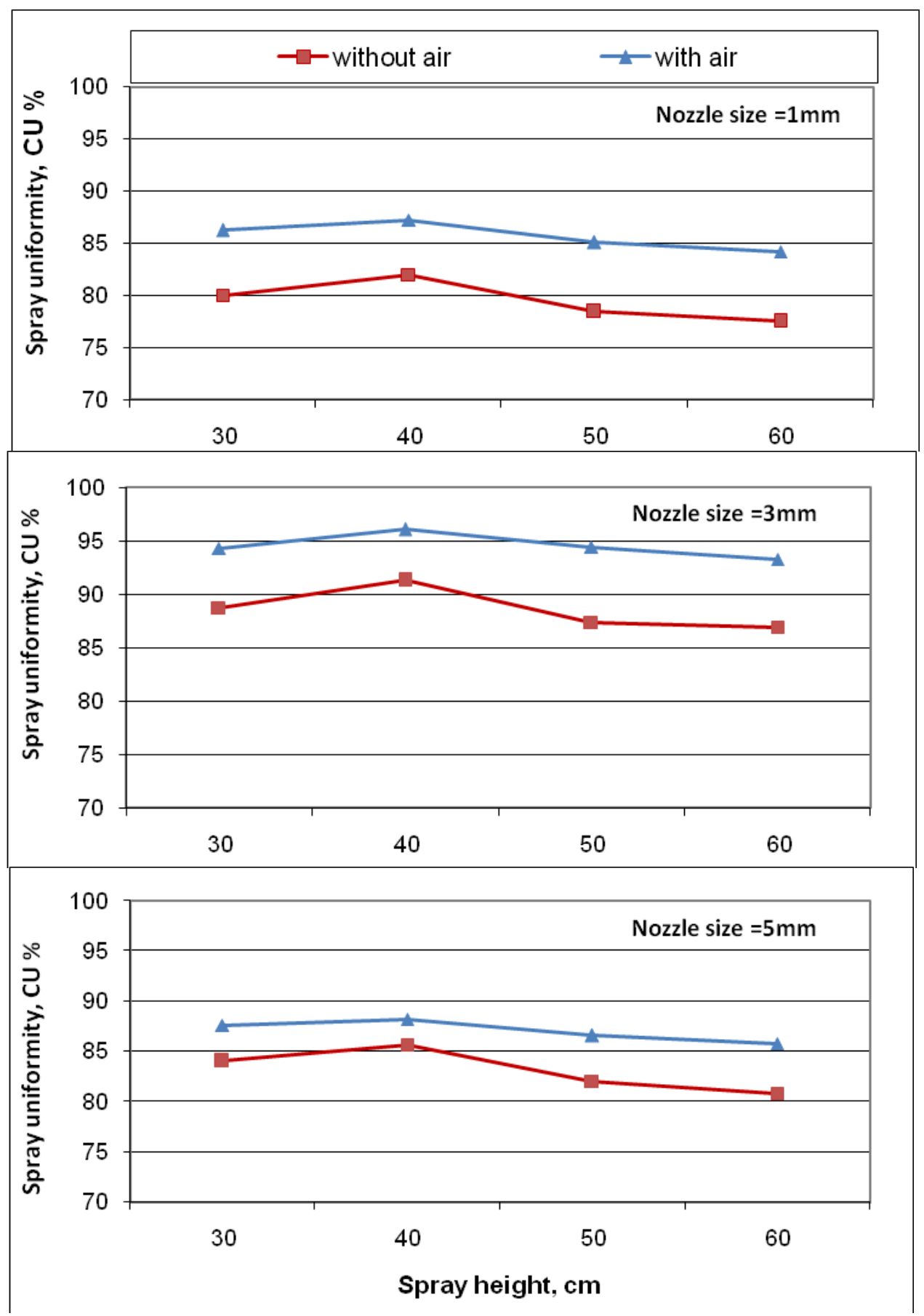

Fig. (3): Relation between spray height and the coefficient of uniformity, CU\% at spray pressure 2.5 bar with and without air assisted unit at overlap $100 \%$. 
The longest distances, from the last nozzle, which the spray drift droplets reached to were $7 \mathrm{~m}$, by using nozzle tip size $1 \mathrm{~mm}$ and $4 \mathrm{~m}$ by using nozzle tip sizes of 3 and $5 \mathrm{~mm}$ at any given spray height and spray pressure levels without using air assisted unit compared with $7 \mathrm{~m}$ by using nozzle tip size of $1 \mathrm{~mm}, 4 \mathrm{~m}$ by using nozzle tip size of $3 \mathrm{~mm}$ and 2 $\mathrm{m}$ by using nozzle tip size of $5 \mathrm{~mm}$ when using air assisted unit of spray device under the highest spray height and spray pressure.

The effect of using air assistance technique was highly significant with nozzle tip size of $1 \mathrm{~mm}$ than with other nozzle tip sizes of 3 and $5 \mathrm{~mm}$. The off-target distance decreased from 7 to $4 \mathrm{~m}$ by using nozzle tip size of $3 \mathrm{~mm}$ and air assistance and decreased from 4 to $2 \mathrm{~m}$ by using tip size of $5 \mathrm{~mm}$ and air assistance at any given spray height and pressure level.

\section{Effect of air assisting on deposition characteristics}

\section{$\underline{\text { 4.1. Droplets numbers } / \mathrm{cm}^{2}}$}

Fig. (5) illustrates the relation between numbers of droplet $/ \mathrm{cm}^{2}$ and spray pressure, by using nozzle tip sizes 1,3 and $5 \mathrm{~mm}$ at the upper and lower plant leave surfaces at the three levels of plant height by using spraying device with and without air assisted units. The droplets $/ \mathrm{cm}^{2}$ increased by increasing the spray pressure and decreased by increasing spray height. Also, at any given spray pressure, the number of droplets $/ \mathrm{cm}^{2}$ decreased as the nozzle tip size increased. At the top level of plant the highest values obtained on the upper leaves surfaces were 32.12, 35.60, 38.47 and 44.01 droplets $/ \mathrm{cm}^{2}$ by using nozzle tip size of $1 \mathrm{~mm}$ without air assisted spraying device under spray pressure of 1.5, 2.5, 3.5 and 4.5 bar respectively, at spray height of $40 \mathrm{~cm}$ compared with $34.82,38.73,42.95$ and 41.97 droplets $/ \mathrm{cm}^{2}$ using the same mentioned spray conditions with air assisted unit. At the bottom of plant levels, the nozzle tip size of $1 \mathrm{~mm}$ gave the highest number of droplets $/ \mathrm{cm}^{2}$ by using with air assisting on the upper and lower leaf surfaces, which were $30.30,33.85,36.45$ and 41.39 droplets $/ \mathrm{cm}^{2}$ and 19.92, $21.96,24.77$ and 31.13 droplets $/ \mathrm{cm}^{2}$ at spray pressures of 1.5, 2.5, 3.5 and 4.5 bar respectively, at spray height of $40 \mathrm{~cm}$. 


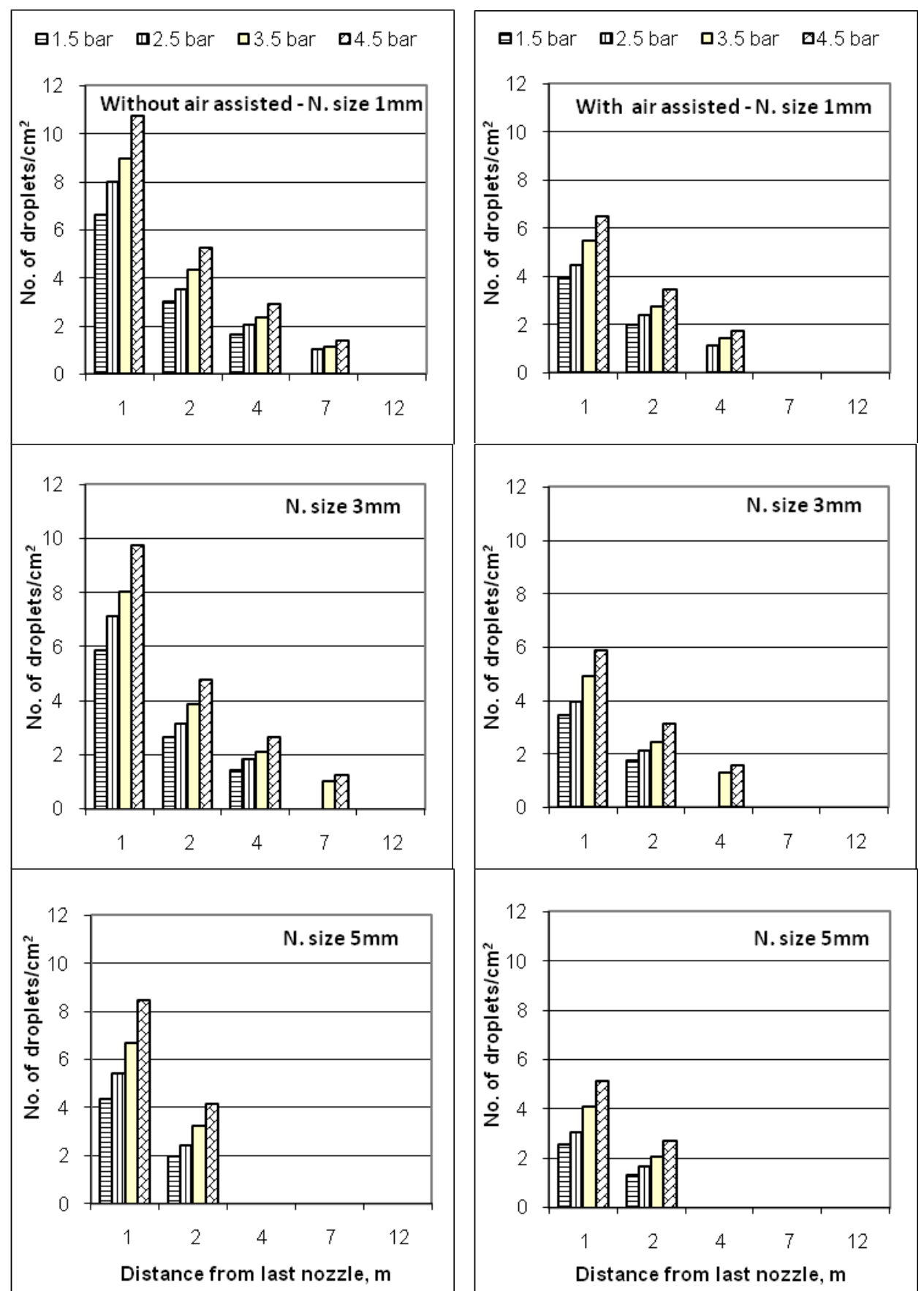

Fig. (4): Number of spray drift droplets at different distance from the last nozzle at different spray pressure, spray height $40 \mathrm{~cm}$ and average wind speed $1.26 \mathrm{~m} / \mathrm{s}$ using with and without air assisted unit. 

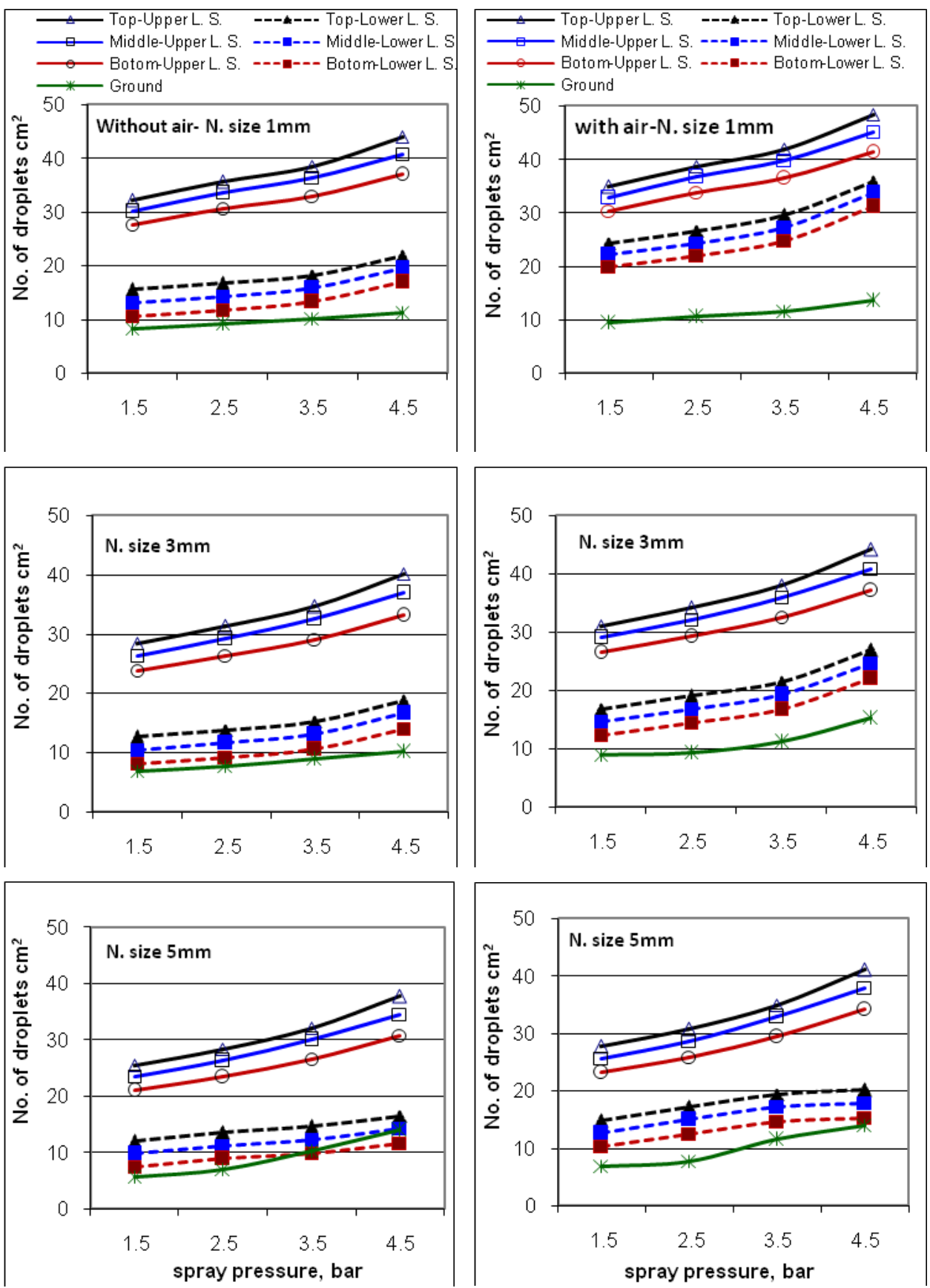

Fig. (5): Relation between spray pressure and number of droplets $/ \mathrm{cm}^{2}$ on the upper and lower plant leaf surfaces at different levels of plant height using spray height $40 \mathrm{~cm}$ for laboratory spraying device with and without air assisted unit.

The $17^{\text {th }}$. Annual Conference of the Misr Society of Ag. Eng., 28 October, $2010 \quad-1665-$ 
The number of droplets loss on the ground, collected by water sensitive paper between cotton rows, was different from one nozzle to another as well as from spray height and pressure level to another. The values of No. of droplets $/ \mathrm{cm} 2$ on the ground were $8.29,9.13,10.17$ and 11.26 by using nozzle tip size of $1 \mathrm{~mm}$ compared with 6.91, 7.72, 8.83 and 10.09 by using nozzle tip size of $3 \mathrm{~mm}$ and $5.70,7.00,10.40$ and 14.00 by using nozzle tip size of $5 \mathrm{~mm}$ at spray height of $40 \mathrm{~cm}$ and spray pressure levels of 1.5, 2.5, 3.5 and 4.5 bar respectively.

\subsection{Volume median diameter, VMD}

\section{The effect of using air assisted unit}

Fig.(6) shows the values obtained of VMD by using nozzle tip size of 1 $\mathrm{mm}$ without air assisted unit at spray height of $40 \mathrm{~cm}$ at the top of plant level were $223.20,209.98,193.20$ and $182.08 \mu \mathrm{m}$ on the upper surface compared with $197.58,180.90,163.20$, and $150.00 \mu \mathrm{m}$ on the lower surface, while they were at the bottom plant level 218.68, 205.12, 187.68 and $175.10 \mu \mathrm{m}$ on the upper surface compared with 193.13, 176.28, 158.49and $145.18 \mu \mathrm{m}$ on the lower surface. However, these values increased by using the same nozzle tip size and spray height with air assisted unit to $244.63,235.18,218.32$ and $207.57 \mu \mathrm{m}$ on the upper surface at the top of plant level compared with 235.12, 218.89, 200.74 and $186.00 \mu \mathrm{m}$ on the lower surface. meanwhile, at the bottom plant level they were $240.11,230.30,212.80$ and $200.59 \mu \mathrm{m}$ on the upper surface compared with $230.67,214.27,196.03$ and $181.18 \mu \mathrm{m}$ on the lower surface under spray pressure levels of 1.5, 2.5, 3.5 and 4.5 bar respectively.

\section{Deposition rate}

Fig. (7) illustrates the values obtained of the deposition rate on the different levels of plant height. The maximum values of deposition rate were $2.360,2.390,2.450$ and $2.570 \mathrm{~mm}^{3} / \mathrm{cm}^{2}$ at the top level on upper leaf surface and they were $1.040,1.070,1.050$ and $1.040 \mathrm{~mm}^{3} / \mathrm{cm}^{2}$ at the bottom level on lower leaf surface when using spraying device with nozzle tip size of $5 \mathrm{~mm}$ and without air assisted unit at spray height of 40 $\mathrm{cm}$ and spray pressure levels of 1.5, 2.5, 3.5 and 4.5 bar respectively. 


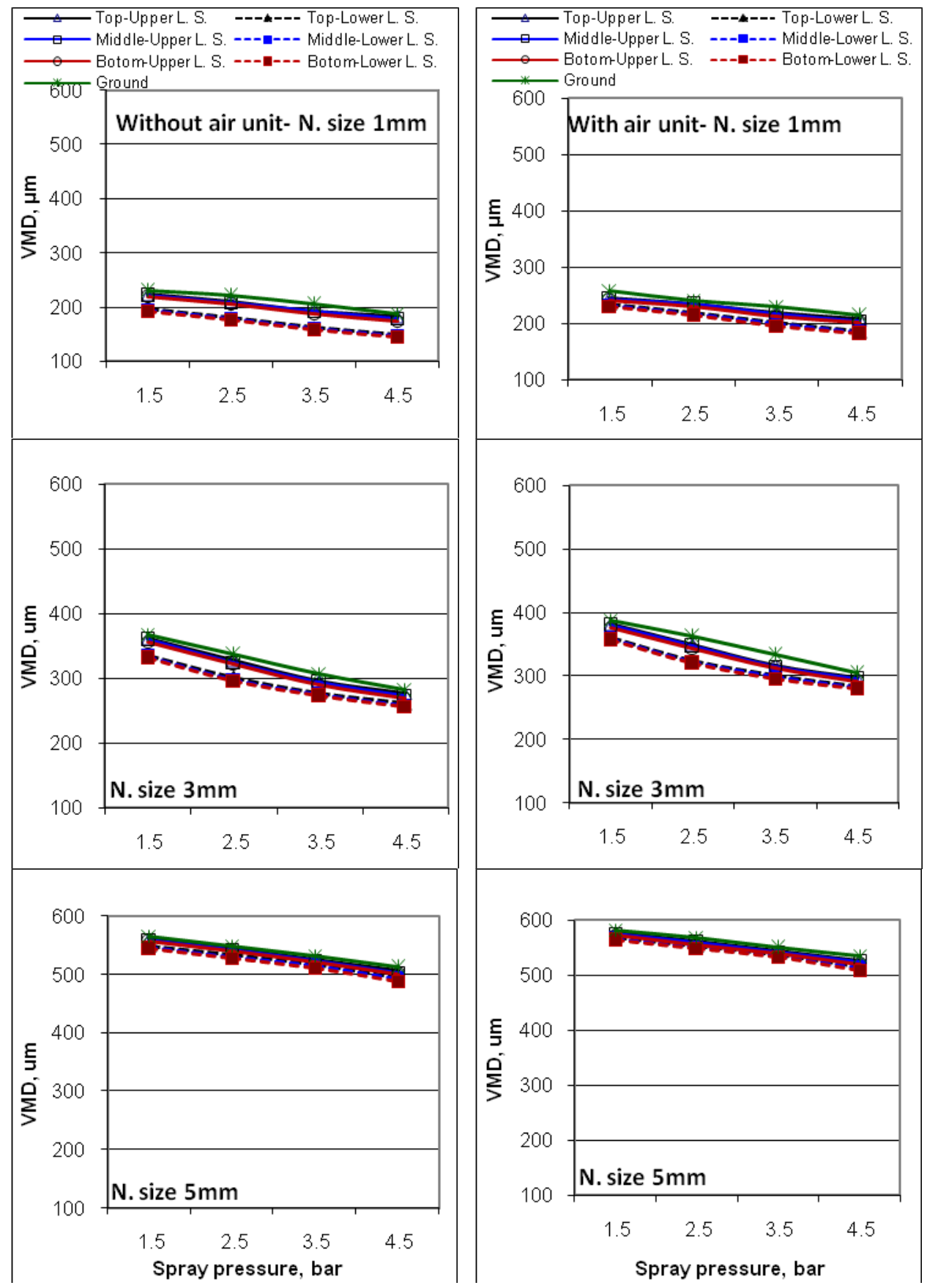

Fig. (6): Relation between spray pressure and volume median diameter (VMD) at spray height $40 \mathrm{~cm}$ using different nozzle tip size with and without air assisted unit. 

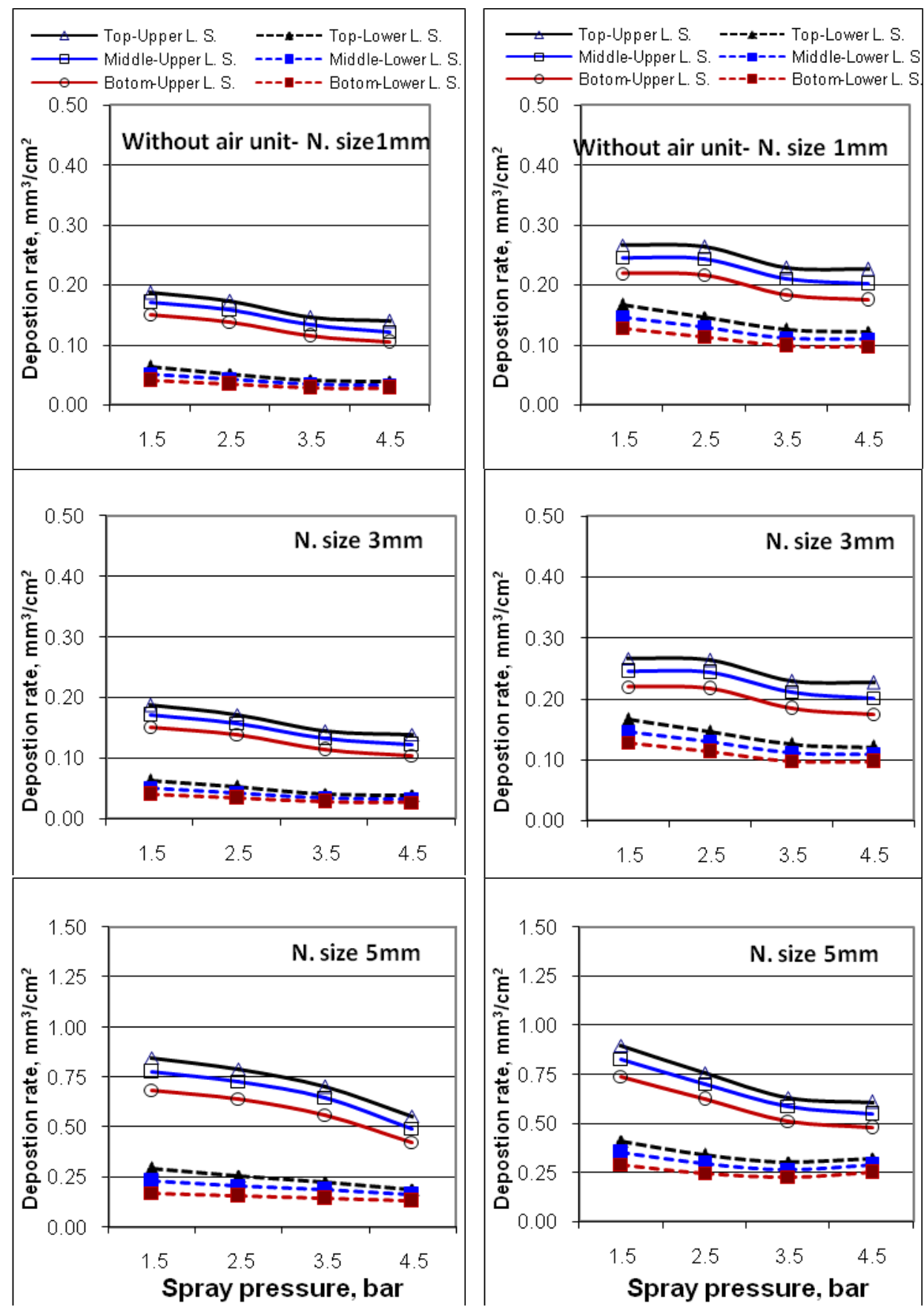

Fig. (7): Relation between spray pressure and deposition rate, $\mathrm{mm}^{3} / \mathrm{cm}^{2}$ under spray height $40 \mathrm{~cm}$ using different nozzle tip size with and without air assisted unit.

The $17^{\text {th }}$. Annual Conference of the Misr Society of Ag. Eng., 28 October, $2010 \quad-1668-$ 
However, in case of using spraying device with air assisted unit the values of deposition rate at the same above mentioned spray condition increased to $2.780,2.830,2.940$ and $3.120 \mathrm{~mm}^{3} / \mathrm{cm}^{2}$ at the top plant level and they increased to $1.410,1.520,1.570$ and $1.420 \mathrm{~mm}^{3} / \mathrm{cm}^{2}$ at the bottom plant level respectively. Also deposition rate increased by increasing the nozzle tip size from $1 \mathrm{~mm}$ to $3 \mathrm{~mm}$ or to $5 \mathrm{~mm}$.

\section{Deposition ratio}

The values obtained of the deposition ratio on the different levels of plant height gave the maximum values of deposition ratio were 0.44 , $0.45,0.43$ and 0.40 at the top level and it were $0.34,0.36,0.35$ and 0.36 at the bottom level when using spraying device with nozzle tip size of $5 \mathrm{~mm}$ and without air assisted unit at spray height of $40 \mathrm{~cm}$ and spray pressure levels of 1.5, 2.5, 3.5 and 4.5 bar respectively. However, in case of using spraying device with air assisted unit the values of deposition ratio at the same above mentioned spray condition increased to $0.51,0.54,0.53$ and 0.46 at the top plant level and they increased to $0.43,0.47,0.48$ and 0.50 at the bottom plant level respectively.

\section{SUMMARY AND CONCLUSION}

The laboratory device of air-assisted spraying was designed and fabricated to control or minimize the spray drift. The objective of this investigation is to study and evaluate the effect of spray drift by using air-assisted spraying technique. The obtained results of the experimental work can be summarized and concluded in the following points:-

- The maximum values of the coefficient of uniformity were at $40 \mathrm{~cm}$ spray height and 2.5 bar spray pressure with $110^{\circ}$ flat fan nozzle tip size of $3 \mathrm{~mm}$.

- The spray drift losses increased by a range of 2.04- 9.78\%, 1.02- 4.89 $\%$ and $1.16-9.98 \%$ with air assisted unit using 1,3 and $5 \mathrm{~mm}$ nozzle tip sizes, respectively.

- The number of droplets/cm2 drift off-target area was found to be 9.73, 4.76, 2.66, 1.24 and 0.00 droplets/cm2 at distance of $1,2,4,7$, and $12 \mathrm{~m}$ respectively, without using air assisted units in comparison with $5.88,3.12,1.56,0.00$ and 0.00 droplets/cm2 by using air assisted 
unit under spray condition of $40 \mathrm{~cm}$ spray height, $3 \mathrm{~mm}$ nozzle tip size and 4.5 bar spray pressure.

- The highest values of the number of droplets at the top level of plant obtained on the upper leaves surface were 32.12, 35.60, 38.47 and 44.01 droplets $/ \mathrm{cm}^{2}$ by using nozzle tip size of $1 \mathrm{~mm}$ without air assisted unit of spraying device under spray pressure of 1.5, 2.5, 3.5 and 4.5 bar respectively, at spray height of $40 \mathrm{~cm}$ compared with $34.82,38.73,42.95$ and 41.97 droplets $/ \mathrm{cm}^{2}$ using the same previously mentioned spray conditions with air assisted unit.

- . The obtained values of (VMD) were increased by using the same nozzle tip size $3 \mathrm{~mm}$ and spray height $40 \mathrm{~cm}$ from $209.98 \mu \mathrm{m}$ without air assisted to $235.18 \mu \mathrm{m}$ with air assisted unit.

- In case of using spraying device with air assisted unit, the values of deposition ratio increased to $0.44,0.45,0.43$ and 0.40 at the top plant level at spray height of $40 \mathrm{~cm}$, using nozzle tip size $5 \mathrm{~mm}$ and spray pressure levels of $1.5,2.5,3.5$ and 4.5 bar respectively

\section{REFERENCES}

ASAE Standard (1992). Test procedure for dry fertilizer speaders Ag. Eng. Yearbook.

Awady, M. (2000). Engineering of sprayers and dusters, and distribution of agriculture text Bk., Col. Ag., A. shams U. :160p (In Arabic)

Carlsen, S.C.K.; N.H. Spliid and B. Svensmark (2006). Drift of 10 herbicides after tractor spray application. 2. Primary drift (droplet drift). Chemosphere (64): 778-786.

Cordell, S. and P. Baker (1998) Cooperative extension, col. Ag. U. Arizona - AZ1050.

Combellack, J.H. (1982). Loss of herbicides from ground sprayers. Weed Res. 22: 193-204.

De Longueville, L; B. Tychon; B. Leteinturier and P. Ozer (2007). An approach to optimize the establishment of grassy headlands in the Belgian Walloon region: A tool for agri-environmental schemes. Land Use Policy 24, 443-450. 
Delele, M. A; P. Jaeken; C. Debaer; K. Baetens; A. Melese Endalew; H. Ramon; B. M Nicolaï and P. Verboven (2007). CFD prototyping of an air-assisted orchard sprayer aimed at drift reduction. Computers and Electronics in Agriculture. 55: 16-27.

Farooq, M.; R. Balachandar; D. Wulfsohn and T.M. Wolf (2001). Agricultural sprays in cross-flow and drift. JAE Res. 78: 347-358.

Gil, Y. and C. Sinfort (2005). Emission of pesticides to the air during sprayer application: a bibliographic review. Atmospheric Environment 39: 5183-5193.

Hadar, E. (1991). Development criteria for an air-assisted ground crop sprayer. In A. Lavers et al. (ed.) Air-assisted spraying in crop protection. BCPC Monogr. 46. Brit. Crop Protect. Council, Bury St. Edmunds, England.

Hardi International Technical Report (1998). Hardi I. Spraying Co. 895411-GB-98/12.

Hardi nozzle technical guide (2007). Hardi iso nozzle Hia-marketing GB-891621-05-2007.

Hewitt, A.J. (2000). Spray drift: impact of requirements to protect the environment. Crop Prot. 19:623-627.

Imara, Z.M.; M.A. Metwally and N.M. Awad (2003). Study of some factors affecting the application uniformity and distribution patterns of two different sprayers. MJAE., 15-16 Oct.

Kappel, D. and C.S. stentrop (2003). Twin spraying - HIA technical report.

Ozkan, E. (2000). Department of food, agricultural and biological engineering Ohio State U. Ext. bulletin 816-00 [online] Available: http://ohioline.ag.ohio-state.edu/ ohioline/b816/index.html [2000, July 6].

Ozkan, H.E.; D.L. Rechard and K.D. Ackerman (1992). Effect of orifice wear on spray patterns from fan nozzles. Trans. of the ASAE, 35 (4): 1091-1096. 
Schultz, R. (2004). Field studies on exposure, effects, and risk mitigation of aquatic non-point source insecticide pollution: a review. J. Envi. Quality 33: 419-448.

Taylor, W.A.; P.G. Andersen and S. Cooper (1989). The use of air assistance in a field crop sprayer to reduce drift and modify drop trajectories. Proceedings of Brighton Crop Prot. Conf - Weeds.: 631-639.

Van de Zande, J.C.; H.J. Holterman; J.M. Michielsen and H. Stallinga (2006). Temporal and spatial variability of spray drift around a sprayed field. Aspects of Applied Biology, vol. 77. Advances in Pesticide Application.: 295-302.

\section{الملخص العزبي}

\section{الرش المساعد هوائيا وانجرافه}

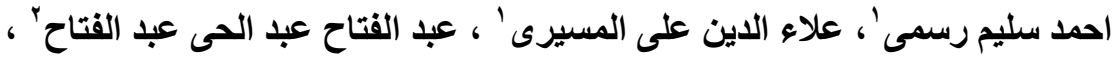

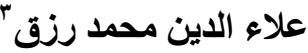

تعتبر تقنبه النظام الثنائى من الطرق الحديثة فى نظم الرش حيث هى عبارة عن مصدر للرش الرش

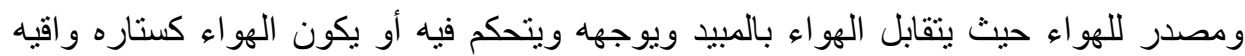

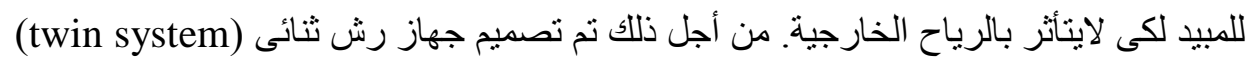
كنموذج أولى وتم دراسة العو امل التالية:

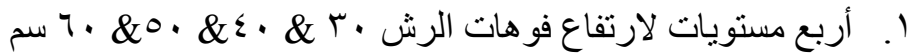

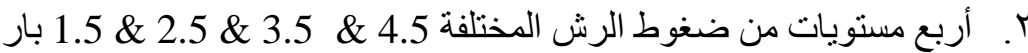

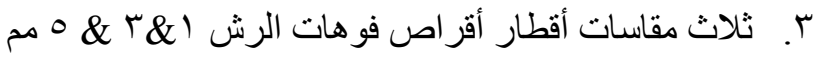

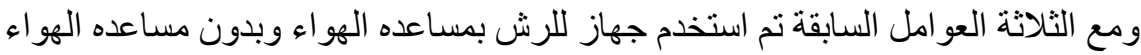
وكانت أفضل النتائج كالاتى:

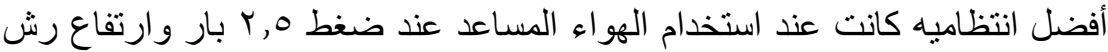

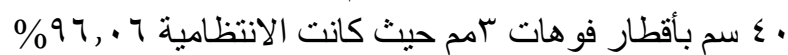

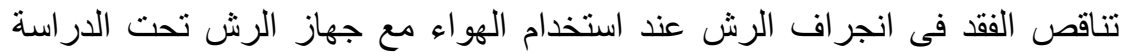

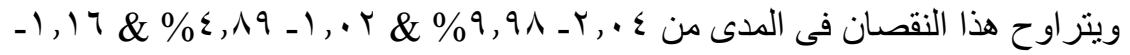

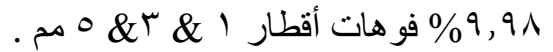

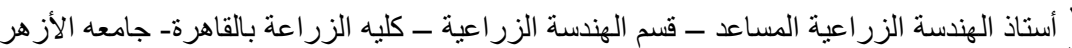

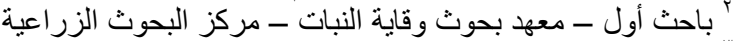

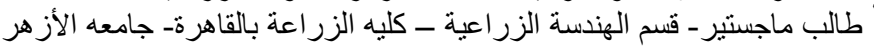




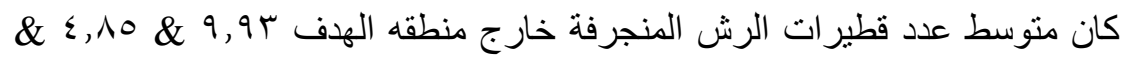

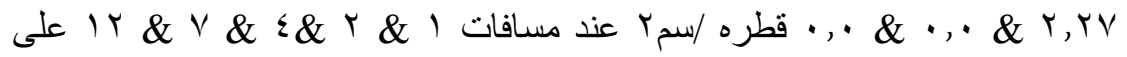

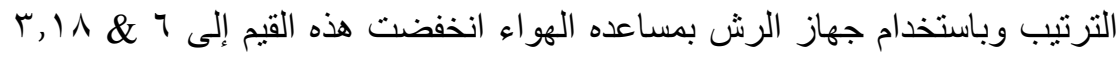

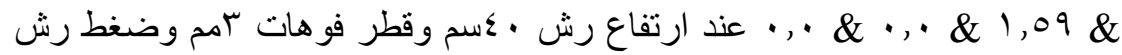

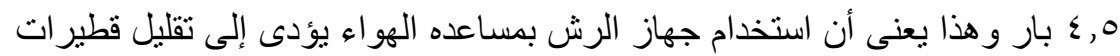

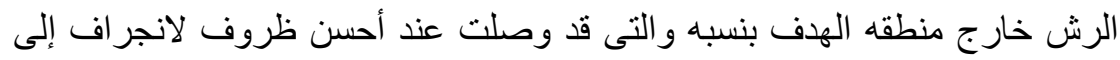

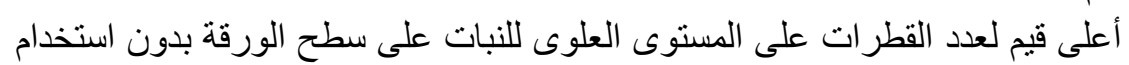

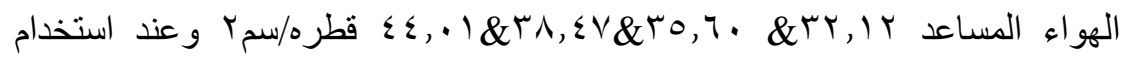

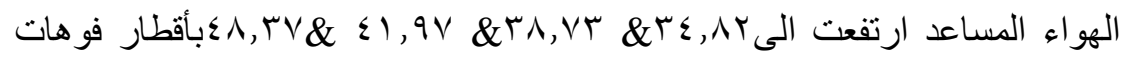

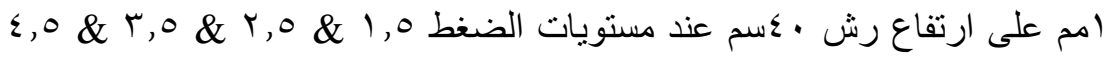

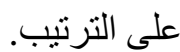

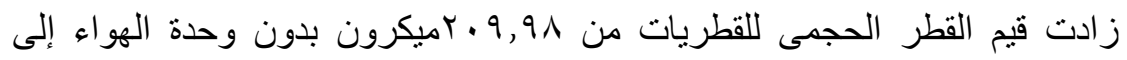

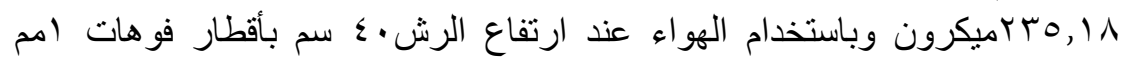

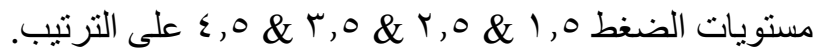

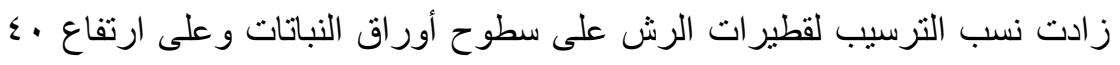

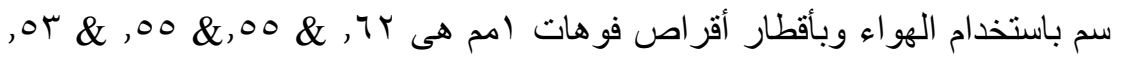

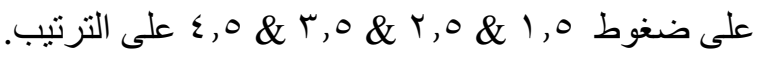

